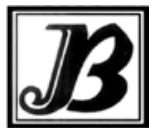

J. Bio-Sci. 26: 25-30, 2018

ISSN 1023-8654

http://www.banglajol.info/index.php/JBS/index

\title{
ASSESSMENT OF THE INSECTICIDAL PROPERTY OF THE PEPPER CAPSICUM ANNUUM EXTRACTS ON THE LARVAL STAGES OF THE TOMATO LEAFMINER TUTA ABSOLUTA (LEPIDOPTERA: GELECHIIDAE)
}

\author{
Merabti $\mathrm{B}^{1,2}{ }^{*}$, Lebbouz $\mathrm{I}^{3}$, Nouioui $\mathrm{I}^{3}$, Aissaoui $\mathrm{H}^{3}$, Ouakid $\mathrm{ML}^{4}$ \\ ${ }^{1}$ Department of Biology, Faculty of Sciences, Amar Telidji University, Laghouat, Algeria \\ 2Desertification and Climate Team, Mechanics Laboratory, Amar Telidji University, Laghouat, Algeria \\ ${ }^{3}$ Departement of Biology, Faculty of Sciences, Mohamed kheider University, Biskra, Algeria \\ ${ }^{4}$ Department of Biology, Faculty of Sciences, Badji Mokhtar University, Annaba, Algeria
}

\begin{abstract}
The aqueous fruit extracts of the pepper Capsicum annuum L. (Solanales: Solanceae) were tested against the four larval stages of the tomato leafminer (TLM) Tuta absoluta Povolny (Lepidoptera: Gelechiidae). Random samplings were made from two greenhouses of Biskra, in the Southeast of Algeria. About 750 to 800 plants of the Sahara variety of tomatoes were planted in both greenhouses. In the laboratory, conditions with temperature, relative humidity $(\mathrm{RH})$ and the photoperiod were $25^{\circ}$ to $30^{\circ} \mathrm{C}$, from $50 \%$ to $60 \%$ and $16 \mathrm{~L}: 8 \mathrm{D}$, respectively. A breeding of our species in the laboratory was made during six months of the study. For the toxicological assessments, three concentrations were chosen; $50 \mathrm{mg} / \mathrm{L}, 100 \mathrm{mg} / \mathrm{L}$ and $200 \mathrm{mg} / \mathrm{L}$ of the extracts. The results revealed that the extracts of $C$. annuum were very effective against the larvae of $T$. absoluta. After $24 \mathrm{~h}$ post-treatment, the mortality was less than $25 \%$ compared to that after $48 \mathrm{~h}$ and $72 \mathrm{~h}$ post-treatment which exceeded $50 \%$. There was a non-significant difference in mortality rates between the four larval stages $\left(F_{3}, 140=1.12 ; P=0.344\right)$. In contrast, highly significant differences existed between the time of exposure $\left(F_{2}, 141=26.2 ; P=0.001\right)$ and the concentrations under study $\left(F_{3}, 140=59.6 ; P=0.001\right)$.
\end{abstract}

Key words: Bio-insecticide, Capsicum annuum, Larval stages, Pepper, Tomato leafminer, Tuta absoluta

\section{Introduction}

The tomato is the culture which presents excellent qualities as festive as nourishing; it constitutes dietary source rich in vitamins and mineral salts (Kononkov and Vemulapalli 1988). At the world level, China is the first world producer of tomato with over $24 \%$ of the total world production in 2009 . This production is mainly intended for the local consumption. The United States, which produces $10 \%$ of the world production occupies the $2^{\text {nd }}$ position. They are followed by India, Turkey, Egypt and Italy. These six countries ensure more than $60 \%$ of the total world production. They are followed by 3 other producers who are Iran, Spain and Brazil (Heuse et al. 2013). The tomato production of Algeria in 2011 is 7.9 million qx for 18000 hectares of a surface (Heuse et al. 2013).

About one-third of the world agricultural production is destroyed by various devastating factors such as insects and fungal and/or viral diseases which cause enormous damages in the sowing's culture until their marketing (Thrupp 2000, Vega 2009). Whiteflies, aphids, leaf miners, acarids, thrips, noctuids, and bedbugs constitute the main devastating arthropods in greenhouses (Nicholls et al. 1998, Mascarin and Jaronski 2016). In recent years, the tomato leafminer (TLM) Tuta absoluta, a new but notorious pest of tomato, is reported to cause considerable losses both in greenhouses and fields (Chidege et al. 2016, Shashank et al.

*Author for correspondence: ecobiskra@hotmail.fr 
2015). Fight against TLM remains very difficult, because the insect exhibited a great resistance to many insecticides (Siquira et al. 2000, Haddi et al. 2012, Roditakis et al. 2013, Barakat et al. 2015). T. absoluta is a microlepidopteran insect native to South America (Torres et al. 2001, Brito et al. 2015, VMK 2017), which can attack all aerial parts such as leaves, flowers, stems and fruits of the tomato plant (Karadjova et al. 2013). This pest can cause up to $100 \%$ damage (Moreira et al. 2004, Niedmann and Meza-Basso 2006). It was first reported in Algeria in 2008 (Desneux et al. 2010).

The chemical fight against insects proved inconvenient to non-target fauna (Fradin and Day 2002). Alternative methods like biological and photochemical controls therefore have gained much attention to the scientists (Hanafy and El-Sayed 2013, Barakat et al. 2015). Numerous plants exhibit toxicological effects against many insect species, reducing their development and population growth (Gurjar et al. 2012, Shiberu and Getu 2016). We aimed by the present investigation at assessing the insecticidal properties of the aqueous fruit extracts of $C$. annuum against the larvae of $T$. absoluta under laboratory conditions.

\section{Materials and Methods}

Area study: Two study sites were chosen for sampling. The first one was El-Maleh site (Sidi Okba: $\left.34^{\circ} 44^{\prime} 54.44^{\prime \prime} 5^{\circ} 53^{\prime} 59.98^{\prime \prime} \mathrm{E}\right)$, situated $10 \mathrm{~km}$ Southeast of Biskra (Algeria), which covered an area of 12.5 ha. Vegetable crops, plastic crops, olive trees and date palms are grown on this site. The second site was M'Ziraa ( $34^{\circ} 49^{\prime} 54.89$ "N $6{ }^{\circ} 16^{\prime} 59.68^{\prime \prime} \mathrm{E}$ ), located $80 \mathrm{~km}$ East of Biskra, extended over an area of 42 ha and dominated by market gardening and greenhouses cultures.

Sampling method and breeding of the insects: For the collection of insect specimens, one greenhouse from both sites was selected, in which 750 to 800 Sahara variety of the tomato plants were planted. Different stages of the larvae of the tomato leafminer (TLM) Tuta absoluta Povolny, 1917 (Lepidoptera: Gelechiidae) were applied to tomato leaves during October 2012 and March 2013, maintaining 20m is the distance between two consecutive plants. Infested leaves by the TLM were kept in cool plastic bags to prevent them from drying out. In the laboratory conditions with temperature $\left(25^{\circ}\right.$ to $\left.30^{\circ} \mathrm{C}\right)$, relative humidity (RH) $50 \%$ to $60 \%$ and the photoperiod (16L: 8D). Entomological forceps and needles were used to extract the larvae for placing under the binocular loupe for examination of the different stages. Adults were paired as soon as they emerged and placed in glass petri dishes each carrying a tender tomato leaf that will support egg-laying by the female moths.

Preparation of the aqueous extracts: Preliminary surveys showed that $C$. annuum fruit smell had repulsive effects on certain species of insects. Fine powder was prepared from dried fruits using a kitchen grinder. In three $1000 \mathrm{ml}$ bottles, $0.05 \mathrm{~g}, 0.1 \mathrm{~g}$ and $0.2 \mathrm{~g}$ of the pepper powder were taken to prepare solutions of $50 \mathrm{mg} / \mathrm{l}, 100 \mathrm{mg} / \mathrm{l}$ and $200 \mathrm{mg} / \mathrm{l}$ concentrations, respectively with distilled water. The solution is mixed with a stirrer. The solution was left for $24 \mathrm{~h}$ in a place at ambient temperature and relative humidity, after which it was filtered off with a filter paper.

Toxicological tests: The aqueous extracts of $C$. annuum were sprayed onto petri dishes each containing 10 individuals from each larval stage of the insect (L1 to L4). The same number of larvae was placed in control Petri dishes for each of the concentrations of the extract. Three repetitions for each concentration were made. The mortality rate was calculated in terms of the average of the three determinations each of 10 individuals.

Statistical analysis: The variables measured corresponded to the larval mortality rates, which were corrected by the Abbott's (1925) formula. The collected data were first subjected to angular transformation according to the tables established by Bliss (Fisher and Yates 1938). Then the standardized data were subjected to one-way analysis of variance (ANOVA). To characterize the insecticidal effect of the $C$. annuum 
fruits used, the toxicological parameters and their confidence intervals were determined. The analyses were done using Statistics (version 8.0).

\section{Results and Discussion}

The exposure of the four larval stages ( $L 1$ to $L 4)$ of $T$. absoluta to three different concentrations of the aqueous fruit extracts of $C$. annuum showed a variable toxic effects at different times of exposure $(24,48$ and $72 \mathrm{~h}$ )(Fig. 1). After $24 \mathrm{~h}$ post-treatment, the mortality was less than $25 \%$, whereas for $48 \mathrm{~h}$ and $72 \mathrm{~h}$ posttreatments the mortality exceeded $50 \%$. After $72 \mathrm{~h}$ exposure, however, the younger larvae were much more sensible compared to the older larvae, particularly L4 (Fig. 2).

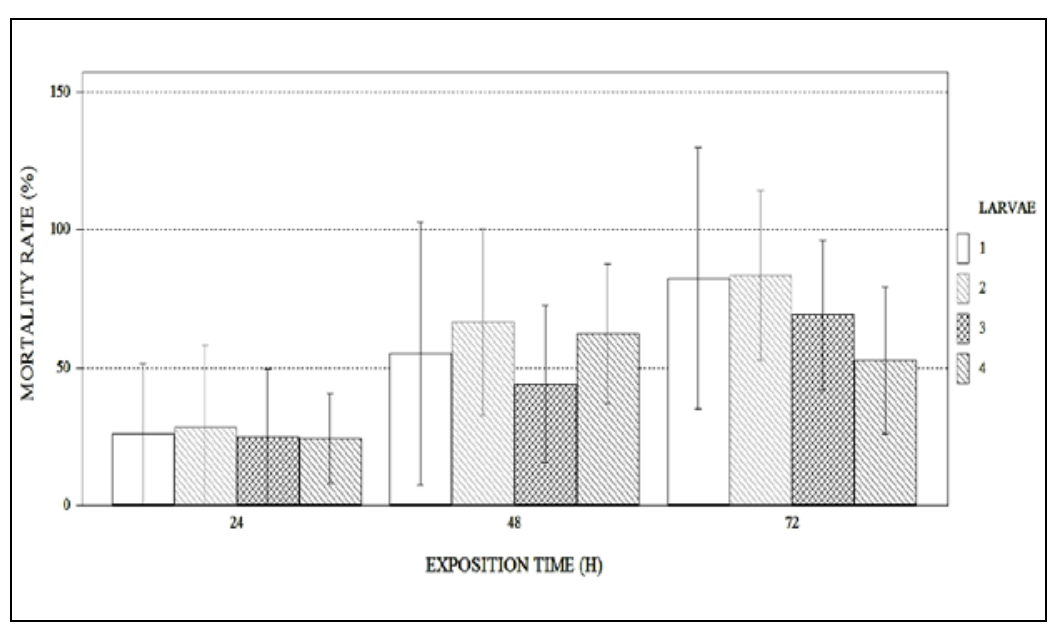

Fig. 1. Mortality of $T$. absoluta larvae against the time of exposure in hrs (1: larval stage 1, 2: larval stage 2, 3: larval stage 3, 4: larval stage 4).

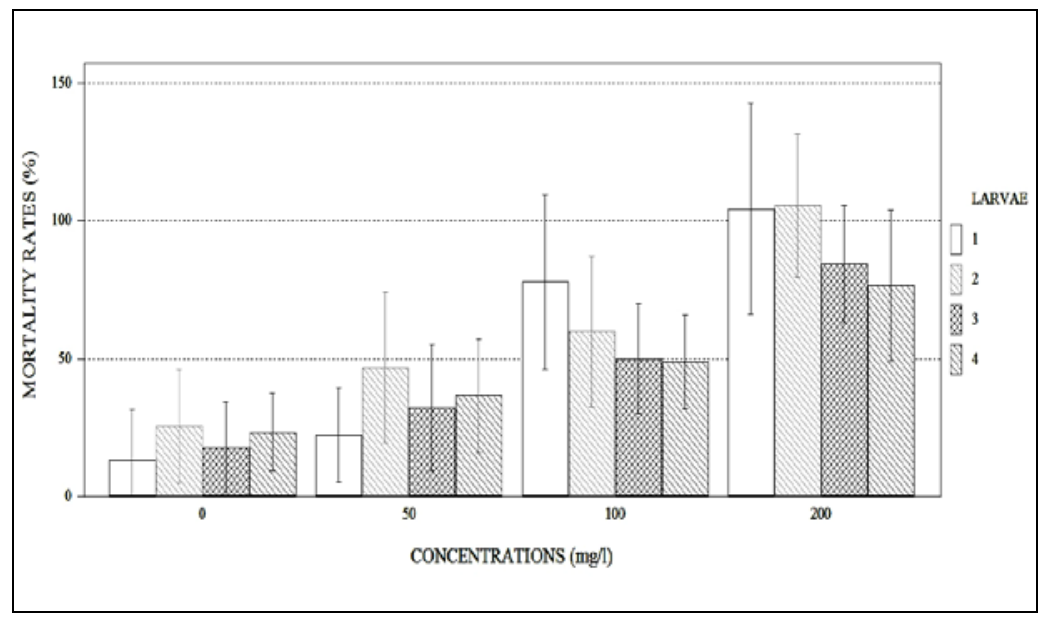

Fig. 2. Mortality of $T$. absoluta larvae against the concentrations applied (1: larval stage 1, 2: larval stage 2, 3: larval stage 3, 4: larval stage 4). 
The analysis of variance (ANOVA) on the experimental data showed that there is not a significant difference between the larval stages come back to the mortality rate $\left(\mathrm{F}_{3}, 140=1.12 ; p=0.344\right)$. But a highly significant differences were found to exist between the three exposure times $\left(F_{2,141}=26.2 ; p<0.001\right)$ and of the three concentrations used $\left(F_{3}, 140=59.6 ; p<0.001\right)$.

The toxicological parameters revealed strong correlation values between concentrations, and mortality rates in the first order and also a high correlation between mortality rate and exposure time when $\mathrm{R}^{2}$ values ranged between 0.755 and 0.949 . The LD $D_{50}$ calculated to have an interval of $180.9 \mathrm{mg} / \mathrm{l}$ to $556.2 \mathrm{mg} / \mathrm{l}$ in the first and last larval stage consecutively. On the other hand, the calculated LDgo had an interval of 211 to $989 \mathrm{mg} / \mathrm{l}$ in the first and last larval stage consecutively (Table 1). It was therefore clear from the results that as larvae grew bigger they needed more treatment product and more exposure time for the effect to be increased.

Table1. Toxicological parameters of $C$. annuum fruit extracts against $T$. absoluta larval stages

\begin{tabular}{|c|c|c|c|c|c|}
\hline \multicolumn{2}{|c|}{$\begin{array}{l}\text { Larval stages } \\
\text { treated }\end{array}$} & Correlation equations & $\begin{array}{c}\text { Confession of } \\
\text { correlation }\end{array}$ & $\begin{array}{c}\text { LLLD50<LD50< ULLD50 } \\
(\mathrm{mg} / \mathrm{l})\end{array}$ & $\begin{array}{c}\text { LLLD } 90<\text { LD } 90<\text { ULLD90 } \\
(\mathrm{mg} / \mathrm{l})\end{array}$ \\
\hline \multirow{3}{*}{ L1 } & $24 \mathrm{~h}$ & $y=1.9932 x-0.3795$ & $R^{2}=0.949$ & \multirow{3}{*}{$121.6<180.9<207.6$} & \multirow{3}{*}{$191.6<211.7<277.5$} \\
\hline & $48 \mathrm{~h}$ & $y=2.1593 x-0.3411$ & $R^{2}=0.941$ & & \\
\hline & $72 \mathrm{~h}$ & $y=3.7372 x-3.8982$ & $\mathrm{R}^{2}=0.841$ & & \\
\hline \multirow{3}{*}{ L2 } & $24 \mathrm{~h}$ & $y=1.9932 x-0.6861$ & $R^{2}=0.939$ & \multirow{3}{*}{$132.8<169.6<221.5$} & \multirow{3}{*}{$272.8<287.1<391.56$} \\
\hline & $48 \mathrm{~h}$ & $y=1.445 x+1.4982$ & $R^{2}=0.897$ & & \\
\hline & $72 \mathrm{~h}$ & $y=3.2721 x-1.753$ & $R^{2}=0.756$ & & \\
\hline \multirow{3}{*}{ L3 } & $24 \mathrm{~h}$ & $y=1.32 x-0.456$ & $\mathrm{R}^{2}=0.755$ & \multirow{3}{*}{$144.7<156.2<231.8$} & \multirow{3}{*}{$389.7<479.2<678.8$} \\
\hline & $48 \mathrm{~h}$ & $y=3.67 x+0.982$ & $R^{2}=0.922$ & & \\
\hline & $72 \mathrm{~h}$ & $y=1.71 x-0.553$ & $\mathrm{R}^{2}=0.834$ & & \\
\hline \multirow{3}{*}{ L4 } & $24 \mathrm{~h}$ & $y=2.32 x-0.8823$ & $R^{2}=0.839$ & \multirow{3}{*}{$404.7<556.2<891.9$} & \multirow{3}{*}{$709.7<989.6<1281.02$} \\
\hline & $48 \mathrm{~h}$ & $y=2.45 x+1.82$ & $R^{2}=0.8978$ & & \\
\hline & $72 \mathrm{~h}$ & $y=4.2721 x+0.753$ & $R^{2}=0.852$ & & \\
\hline
\end{tabular}

L1-L4 represents the larval stages of $T$. absoluta; LLLD 50 : Lower limit of lethal concentrations 50, LD $_{50}$ : lethal

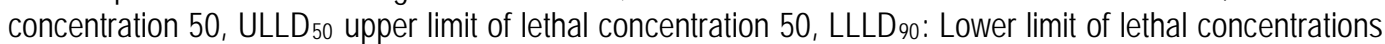
90, LD 90 : lethal concentration 90, ULLD90 upper limit of lethal concentration 90.

Previous reports showed that the larvae of $T$. absoluta caused yield losses of up to $100 \%$ by attacking leaves, flowers, roots, and fruits (Barrientos et al. 1998, Chidege et al. 2016, VMK 2017). The results by Gacemi and Guenaoui (2012), who used Spinosad (Azadirachtin indica) and an insecticide Emamectin benzoateun against $T$. absoluta, showed excellent efficacy with $86.7 \%$ mortality on average and the persistence of the product was between 7 and 14 days. The present results are comparable to those showed by López et al. (2010) when they obtained a larval mortality rate of $90 \%$ on tomato leaves. The present results are encouraging in terms of good larvicidal activity of the aqueous fruit extracts of $C$. annuum against the larval stages of the TLM, in which up to $100 \%$ mortality after $72 \mathrm{~h}$ exposure at $200 \mathrm{mg} / \mathrm{l}$ was achieved. The early larval instars ( $L 1$ and L2) were sensitive to the treatments compared to the final larval instars (L3 and L4). These findings indicate that the pepper extracts can be used as a natural insecticide to fight against the notorious TLM T. absoluta. 
The toxic effect of C.annuum extracts has been mentioned in several works. Madhumathy et al. (2007) proved its effectiveness against IV instar larvae of Anopheles stephensi and Culex quinquefasciatus. The treated larvae showed curling up, agitation, vigorous body movements which are the characteristic of neurotoxicity. Sukul et al. (1974) have tried the Nematicidal effect of C.annuum. It is recommended to illustrate the effect of primary and secondary metabolites of our fruits on parasitic and pest insects, because of its biodegradability in the marine and terrestrial ecosystem.

\section{Conclusion}

The extract used in this toxicological test is $C$. annuum against $T$. absoluta larvae. He presented an encouraging toxicological effect. The responses of the different larval stages were variable. The most precarious stages have been unsuccessful compared to late stages, which show some resistance. It is advisable to focus our research on the active principles of this extract to determine the active molecule responsible for this toxicity.

\section{Acknowledgements}

This work was done in the master's framework preparation of Nouioui I and Aissaoui H. A big thanks for all peoples who contributed to the realization of this work (Farmer) Laboratories are gratefully recognized.

\section{References}

Abbott WS (1925). A method of computing the effectiveness of an insecticide. J Econ. Ent., 8: 265-267.

Barakat AST, Kordy AM, Rahman TA, Gouda RM and Ibrahiem MAM (2015). Biological activity of some natural plant extracts and bio-pesticides against tomato leafminer, Tuta absoluta (Meyrick) (Lepidoptera: Gelechiidae) and their residues on tomato fruits, Current Science International, 4(1): 10-18.

Barrientos ZR, Apablaza HJ, Norero SA and Estay PP (1998). Threshold temperature and thermal constant for development of the South American tomato moth Tuta absoluta (Meyrick) (Lepidoptera: Gelechiidae). Ciencia e Investigacion Agraria, 25: 133-137.

Brito EFD, Baldin ELL, Silva RDCM, Ribeiro LDP and Vendramim JD (2015). Bioactivity of Piper extracts on Tuta absoluta (Lepidoptera: Gelechiidae) in tomato. Pesquisa Agropecuária Brasileira, 50(3): 196-202

Chidege M, Al-zaidi S, Hassan N, Julie A, Kaaya E and Mrogoro S (2016). First record of tomato leaf miner Tuta absoluta (Meyrick) (Lepidoptera: Gelechiidae) in Tanzania. Agriculture and Food Security, 5(1): 17.

Desneux N, Wajnberg E, Wyckhuys KA, Burgio G, Arpaia S, Narváez-Vasquez CA and Pizzol J (2010). Biological invasion of European tomato crops by Tuta absoluta: ecology, geographic expansion and prospects for biological control. Journal of Pest Science, 83(3): 197-215.

Fisher RA and Yates F (1938). Statistical Table for Biological, Agricultural and Medical Research. Olivier and Boyd, London.

Fradin MS and Day JF (2002). Comparative efficacy of insect repellents against mosquito bites. New England Journal of Medicine, 347(1): 13-18.

Gacemi A and Guenaoui Y (2012). Efficacy of emamectin benzoate on Tuta absoluta Meyrick (Lepidoptera: Gelechiidae) infesting a protected tomato crop in Algeria. Academic Journal of Entomology, 5(1): 37-40

Gurjar MS, Ali S, Akhtar M and Singh KS (2012). Efficacy of plant extracts in plant disease management. Agricultural Sciences, 3(3): 425.

Haddi K, Berger M, Bielza P, Cifuentes D, Field LM, Gorman K, Rapisarda C, Williamson MS and Bass C (2012). Identification of mutations associated with pyrethroid resistance in the voltage-gated sodium channel of the tomato leaf miner (Tuta absoluta). Insect Biochemistry and Molecular Biology, 42(7): 506-513. 
Hanafy HEM and El-Sayed W (2013). Efficacy of bio-and chemical insecticides in the control of Tuta absoluta (Meyrick) and Helicoverpa armigera (Hubner) infesting tomato plants. Australian Journal of Basic and Applied Science, 7(2): 943-948.

Heuze V, Tran G, Bastianelli D, Hassoun P and Lebas F (2013). Tomato pomace, tomato skins and tomato seeds. Feedipedia. Org. A programme by INRA, CIRAD, AFZ and FAO.

Jansson RK, Brown R, Cartwright B, Cox D, Dunbar DB, Dybas RA, Eckel C, Lasota JA, Mookerjee PK, Norton JA, Peterson RF, Starner VR and White S (1996). Emamectin benzoate: a novel avermectin derivate for control of lepidopterous pests. Proceedings of the management of diamonback moths and other cruciferous pests. Chemical Control Entomology. Cornell University, pp. 171-177.

Karadjova O, llieva Z, Krumov V, Petrova E and Ventsislavov V (2013). Tuta absoluta (Meyrick) (Lepidoptera: Gelechiidae): Potential for entry, establishment and spread in Bulgaria. Bulgarian Journal of Agricultural Science, 19(3): 563-571.

Kononkov PF and Vemulapalli K (1988). Vegetable Growing in Home Gardens of Tropical and Subtropical Areas. Mir publishers, Moscow, pp. 1-158.

López JM, Artín LM, López A, Correia R, González F, Sanz E, Gallardo M, Cantus JM (2010). A new weapon against Tuta absoluta and other lepidopteran caterpillars. Phytoma-Spain, 217: 5.

Madhumathy AP, Aivazi AA and Vijayan VA (2007). Larvicidal efficacy of Capsicum annum against Anopheles stephensi and Culex quinquefasciatus. Journal of Vector Borne Diseases, 44(3): 223.

Mascarin GM and Jaronski ST (2016). The production and uses of Beauveria bassiana as a microbial insecticide. World Journal of Microbiology and Biotechnology, 32 (11): 177.

Moreira MD, Picanco MC, Barbosa LCD, Guedes RNC, De Silva LM (2004). Toxicity of leaf extracts of Ageratum conyzoides to lepidopteran pests of horticultural crops. Biological Agriculture and Horticulture, 22(3): 251-260.

Nicholls $\mathrm{Cl}$, Parrella MP and Altieri MA (1998). Advances and perspectives in the biological control of greenhouse pests with special reference to Colombia. Integrated Pest Management Reviews, 3(2): 99-109.

Niedmann LL and Meza-Basso L (2006). Evaluación de cepas nativas de Bacillus thuringiensis como una alternativa de manejo integrado de la polilla del tomate (Tuta absoluta Meyrick; Lepidoptera: Gelechiidae) en Chile. Agricultura Técnica, 66(3): 235-246.

Roditakis E, Skarmoutsou C and Staurakaki M (2013). Toxicity of insecticides to populations of tomato borer Tuta absoluta (Meyrick) from Greece. Pest Management Science, 69(7): 834-840.

Shashank PR, Chandrashekar K, Meshram NM and Sreedevi K (2015). Occurrence of Tuta absoluta (Lepidoptera: Gelechiidae) an invasive pest from India. Indian Journal of Entomology, 77(4): 323-329.

Shiberu T and Getu E (2016). Assessment of selected botanical extracts against Liriomyza species (Diptera: Agromyzidae) on tomato under glasshouse condition. International Journal of Fauna and Biological Studies, 3(1): 87-90.

Siqueira HÁA, Guedes RNC and Picanço MC (2000). Insecticide resistance in populations of Tuta absoluta (Lepidoptera: Gelechiidae). Agricultural and Forest Entomology, 2(2): 147-153.

Sukul NC, Das PK and De GC (1974). Nematicidal action of some edible crops. Nematologica, 20(2): 187-191.

Thrupp LA (2000). Linking agricultural biodiversity and food security: the valuable role of agrobiodiversity for sustainable agriculture. International Affairs, 76(2): 283-297.

Torres JB, Faria CA, Evangelista WSJ and Pratissoli D (2001). Within-plant distribution of the leaf miner Tuta absoluta (Meyrick) immatures in processing tomatoes, with notes on plant phenology. International Journal of Pest Management, 43: 173-178.

Vega FE, Goettel MS, Blackwell M, Chandler D, Jackson MA, Keller S and Pell JK (2009). Fungal entomopathogens: new insights on their ecology. Fungal Ecology, 2(4): 149-159.

VKM (2017). Risk assessment of Tomato leaf miner moth (Tuta absoluta). Scientific Opinion of the Panel on Plant Health of the Norwegian Scientific Committee for Food Safety, Oslo, Norway. 